\title{
PENERAPAN METODE MIND MAPPING DAN MODEL STUDENT FACILITATOR AND EXPLAINING (SFAE) UNTUK MENINGKATKAN HASIL BELAJAR PESERTA DIDIK KELAS VIII A PADA MATERI SISTEM RESPIRASI DI SMP AISYIYAH MUHAMMADIYAH 3 MALANG
}

\author{
Solehah, Riyanto \\ Program Studi Pendidikan Biologi IKIP Budi Utomo Malang \\ email: ${ }^{1}$ sholeha_infenity@yahoo.com; ryn_kebo@yahoo.com
}

\begin{abstract}
Abstrak
Hasil observasi yang telah dilakukan di SMP Aisyiyah Muhammadiyah 3 Malang, menunjukkan bahwa minat peserta didik rendah pada materi biologi. Banyaknya penggunaan bahasa latin atau ilmiah menyebabkan perlunya pemahaman yang tinggi untuk matapelajaran tersebut. Penggunaan model dan metode pembelajaran yang kurang menarik serta kurangnya penggunaan media pembelajaran membuat peserta didik merasa bosan dan kurang aktif saat proses belajar berlangsung. Menanggapi permasalahan tersebut, maka dilakukan penelitian dengan tujuan untuk menanggulangi berbagai permasalahan tersebut di atas. Metode Mind Mapping dan Model Student facilitator and Explaining yang dikolaborasikan dalam suatu pembelajaran diharapkan dapat menjadi solusi bagi permasalahan pembelajaran di SMP Aisyiyah Muhammadiyah 3 Malang dan dapat meningkatkan hasil belajar peserta didik. Penelitian ini merupakan Penelitian Tindakan Kelas (PTK) yang terdiri dari 2 siklus dan terdiri atas 2 pertemuan setiap siklusnya. Satu siklus terdiri dari 4 tahapan yaitu perencanaan, pelaksanaan, observasi, dan refleksi. Subjek penelitian adalah peserta didik kelas VIII A SMP Aisyiyah Muhammadiyah 3 Malang tahun ajaran 2015/2016 pada materi sistem respirasi. Hasil Penelitian dengan penerapan metode Mind Mapping dan model pembelajaran Student Facilitator and Explaining (SFAE) menunjukan adanya peningkatan hasil belajar biologi peserta didik. Hasil belajar kognitif peserta didik diukur melalui persentase (\%) ketuntasan belajar peserta didik dan persentase (\%) ketuntasan belajar klasikal. Persentase ketuntasan belajar peserta didik siklus I ke siklus II secara berturut-turut sebesar 76,92\% dan 96,15\%. Persentase belajar klasikal siklus I dan II berturut-turut sebesar 76,15\% dan 86,73\%. Hasil belajar afektif peserta didik diukur dari rata-rata mengalami peningkatan dari siklus I ke siklus II secara berturut-turut sebesar 75,77 dan 79,80. Hasil belajar psikomotorik peserta didik yang diukur dari ratarata nilai mengalami peningkatan dari siklus I ke siklus II sebesar 77,01 dan 80.

Kata Kunci: Mind Mapping, Student Facilitator and Explaining (SFAE), Hasil Belajar.
\end{abstract}

\section{PENDAHULUAN}

Pendidikan merupakan pendewasaan peserta didik agar dapat mengembangkan bakat, potensi dan keterampilan yang dimiliki dalam menjalani kehidupan (Daryanto, 2012). Pendidikan sudah seharusnya didesain guna memberikan pemahaman dan meningkatkan prestasi atau hasil belajar peserta didik. Pendidikan merupakan sarana untuk menyiapkan generasi masa kini sekaligus masa depan. Hal ini berarti bahwa proses pendidikan yang dilakukan pada saat ini bukan semata-mata untuk hari ini, melainkan untuk masa depan. Pendidikan harus mengantisipasi apa yang akan terjadi dimasa depan (future) dengan 


\section{JEMS (Jurnal Edukasi Matematika dan Sains)}

Tersedia online di: http://e-journal.ikippgrimadiun.ac.id/index.php/JEMS

Volume 4, Nomor 2, September 2016, hal 121-128

membekali berbagai kompetensi yang akan diperlukan dimasa depan (Mulyasa, 2013).

Berdasarkan hasil observasi yang telah dilakukan di SMP Aisyiyah Muhammadiyah 3 Malang kelas VIII A ditemukan beberapa permasalahan yang dihadapi peserta didik pada mata pelajaran Biologi, yaitu kurangnya pemahaman sehingga hasil belajar peserta didik sangat rendah. Faktor yang menyebabkan hal tersebut adalah peserta didik yang kurang mendengar dan memperhatikan materi saat dijelaskan oleh guru, peserta didik bosan untuk mengikuti proses belajar mengajar, pembelajaran yang masih terpusat pada guru (Teacher centered), metode dan model yang digunakan konvensional serta pembelajaran kurang inovatif dan kreatif. Oleh karena itu perlu dicobakan metode dan model pembelajaran yang akan membuat peserta didik memperoleh pengetahuan secara langsung melalui pengalaman sendiri untuk mempelajari tentang diri sendiri dan alam sekitar sehingga peserta didik menjadi lebih kreatif, serta lebih tertarik selama mengikuti pembelajaran, dan dapat menemukan proses pembelajaran yang dialami. Hasil belajar peserta didik diharapkan dapat meningkat pada mata pelajaran biologi, dengan menggunakan model pembelajaran tertentu sehingga akan menentukan tingkat pemahaman dan hasil belajar pada peserta didik dalam mengikuti mata pelajaran biologi yang pada akhirnya akan membantu mencapai tujuan belajar peserta didik.

Metode dan model pembelajaran tersebut bisa mengubah pembelajaran dari yang semula berpusat pada guru menuju pembelajaran yang aktif, inovatif, kreatif, dan menyenangkan yang berpusat pada peserta didik (Student Centered). Peneliti berupaya untuk mengatasi permasalahan tersebut dengan menggunakan metode Mind Mapping yang dikolaborasikan dengan model Student Facilitator and Explaining (SFAE). Hasil penelitian sebelumnya dilakukan oleh Rahmawati. A, Retnowati.R, Kurniasih. S. 2012 mengenai penggunaan metode Mind Mapping ataupun model Student Facilitator and Explaining menunjukkan bahwa model tersebut dapat meningkatkan hasil belajar peserta didik. Berdasarkan uraian di atas, maka peneliti melakukan Penelitian Tindakan Kelas (PTK) dengan menerapkan metode Mind Mapping dan model Student Facilitator and Explaining untuk meningkatkan hasil belajar peserta didik kelas VIII A pada materi sistem respirasi di SMP Aisyiyah Muhammadiyah 3 Malang.

\section{METODE}

Pendekatan yang digunakan dalam penelitian ini adalah pendekatan Kualitatif. Penelitian yang digunakan merupakan Penelitian Tindakan Kelas (PTK) yang dilakukan dalam 2 siklus untuk meningkatkan hasil belajar biologi peserta didik. PTK terdiri dari 4 tahap yaitu perencanaan, pelaksanaan, observasi, refleksi. Instrumen yang digunakan dalam penerapan metode Mind Mapping dan model Student Facilitator and Explaining (SFAE) adalah Rencana Pelaksanaan Pembelajaran (RPP), Lembar Kerja Peserta Didik (LKPD), Lembar Observasi Kegiatan guru dan peserta didik, dan Tes Hasil Belajar. Hasil observasi pelaksanaan pembelajaran Mind Mapping dan model Student Facilitator and Explaining dianalisis secara deskriptif, kemudian hasilnya dibandingkan antara hasil siklus I dan hasil siklus II. Hasil belajar kognitif diambil dari tes setiap akhir siklus yang bertujuan untuk mengetahui peningkatan hasil belajar peserta didik terhadap materi pasca tindakan. Hasil belajar ranah afektif, dan ranah psikomotorik didapatkan dari hasil observasi selama proses pembelajaran serta membandingkan hasil dari akhir siklus I dan siklus II sehingga diketahui hasil belajar peserta didik selama penerapan metode mind mapping dan 


\section{JEMS (Jurnal Edukasi Matematika dan Sains)}

Tersedia online di: http://e-journal.ikippgrimadiun.ac.id/index.php/JEMS

Volume 4, Nomor 2, September 2016, hal 121-128

model Student Facilitator and Expalining yang dikolaborasikan.

\section{HASIL DAN PEMBAHASAN}

\section{A. Hasil Belajar}

Hasil belajar peserta didik dibagi menjadi tiga ranah, yaitu kognitif, afektif dan psikomotorik. Hasil dari penerapan metode mind mapping dan model student facilitator and explaining yang dikolaborasikan dalam meningkatkan hasil belajar peserta didik adalah sebagai berikut:

\section{Ranah kognitif}

Hasil belajar kognitif siswa didapatkan dari hasil tes pada akhir siklus I dan siklus II untuk mengetahui perbandingan hasil belajar kognitif. Hasil belajar kognitif peserta didik siklus I dan siklus II setelah penerapan metode mind mapping dan model student facilitator and explaining yang dikolaborasikan memiliki perbedaan. jumlah peserta didik yang tuntas belajar pada siklus I sebanyak 20 dari jumlah keseluruhan peserta didik adalah 26, sedangkan pada siklus II meningkat menjadi 25. Persentase ketuntasan belajar peserta didik siklus I ke siklus II secara berturut-turut sebesar $76,92 \%$ dan $96,15 \%$. Hal ini menunjukkan adanya peningkatan sebesar 19,23\%. Persentase hasil belajar klasikal didapatkan dari skor yang diperoleh kelas setelah melakukan tes. Persentase hasil belajar klasikal siklus I dan II berturut-turut sebesar $76,15 \%$ dan $86,73 \%$. Hal ini menunjukkan adanya peningkatan sebesar 10,58\%. Data ditunjukkan pada tabel 1 .

Tabel 1. Jumlah \& Hasil Belajar Kognitif Peserta Didik Siklus I dan II

\begin{tabular}{lccc}
\hline $\begin{array}{l}\text { Perbanding } \\
\text { an }\end{array}$ & $\begin{array}{c}\text { Siklus } \\
\text { I }\end{array}$ & $\begin{array}{c}\text { Siklus } \\
\text { II }\end{array}$ & $\begin{array}{l}\text { Peningkat } \\
\text { an }\end{array}$ \\
\hline $\begin{array}{l}\text { Peserta } \\
\text { didik }\end{array}$ & 20 & 25 & 5 \\
$\%$ & & & \\
Ketuntasan & $\begin{array}{c}76,92 \\
\%\end{array}$ & $\begin{array}{c}96,15 \\
\%\end{array}$ & $19,23 \%$ \\
\% Klasikal & $\begin{array}{c}76,15 \\
\%\end{array}$ & $\begin{array}{c}86,73 \\
\%\end{array}$ & $10,58 \%$ \\
& $\%$ & \\
\hline
\end{tabular}

\section{Ranah Afektif}

Hasil belajar afektif peserta didik dapat diketahui dengan menilai sikap saat mengikuti pelajaran disetiap pertemuannya. Sikap peserta didik didapatkan oleh observer saat peserta didik melaksanakan proses pembelajaran di kelas. Sikap dalam proses pembelajaran ini berupa sikap dalam diskusi kelompok maupun sikap saat presentasi kelompok. Rata-rata nilai hasil afektif peserta didik mengalami peningkatan dari siklus I sebesar 75,77 dan untuk siklus II menjadi 79,80 hal ini bisa menunjukan bahwa penigkatan dari ranah afektif sebesar 4,03. Data ditunjukkan pada tabel 2.

Tabel 2. Hasil Belajar Ranah Afektif Peserta Didik Siklus I dan II

\begin{tabular}{lll}
\hline Siklus I & Siklus II & Peningkatan \\
\hline 75,77 & 79,80 & 4,03 \\
\hline
\end{tabular}

\section{Ranah Psikomotorik}

Hasil ranah psikomotorik pada penelitian ini diperoleh dari hasil observasi berupa penilaian selama kegiatan pengamatan berlangsung yaitu melalui keterampilan peserta didik ketika membuat mind mapping dan menjelaskan materi sistem respirasi dengan menggunakan model Student Facilitator and Explaining dalam proses pembelajaran. Rata-rata nilai hasil psikomotorik peserta didik mengalami peningkatan dari siklus I sebesar 77,01 untuk siklus II menjadi 80 hal ini bisa menunjukan bahwa penigkatan dari ranah psikomotorik cukup baik. Data ditunjukkan pada tabel 3 .

Tabel 3. Hasil Belajar Ranah Psikomotorik Peserta Didik Siklus I dan II

\begin{tabular}{lll}
\hline Siklus I & Siklus II & Peningkatan \\
\hline 77,01 & 80 & 2,99 \\
\hline
\end{tabular}

Selama melakukan pengamatan siklus I, aktivitas yang diamati mencakup kegiatan yang dilakukan peserta didik pada saat proses pembelajaran. Berdasarkan 


\section{JEMS (Jurnal Edukasi Matematika dan Sains)}

Tersedia online di: http://e-journal.ikippgrimadiun.ac.id/index.php/JEMS

Volume 4, Nomor 2, September 2016, hal 121-128

hasil analisis data dapat diketahui bahwa penerapan metode Mind Mapping dan model Student Facilitator and Explaining yang dikolaborasikan dapat meningkatkan hasil belajar peserta didik. Adanya peningkatan hasil belajar peserta didik juga disebabkan beberapa faktor, antara lain adanya dorongan motivasi yang diberikan oleh guru berupa pujian-pujian agar dapat lebih berani untuk menjawab, bertanya, dan mengemukakan pendapatnya dalam proses pembelajaran. Motivasi atau sebagai dorongan yang terdapat dalam diri seseorang untuk melakukan sesuai tindakan (Pribadi, 2011).

Penerapan metode Mind Mapping dan model Student Facilitator and Explaining yang dikolaborasikan dari siklus I ke siklus II dapat meningkatkan sikap peserta didik. Perbandingan sikap peserta didik antara siklus I dan siklus II dapat diketahui dari aspek aktivitas yang terdiri dari aspek pembuatan Mind Mapping, aktivitas peserta didik dan penggabungan antara metode Mind Mapping yang dikolaborasikan dengan model Student Facilitator and Explaining dalam kelas dari siklus I dan siklus II. Pada aspek pembuatan mind mapping dan peta konsep yang dikolaborasikan menunjukan bahwa, aktivitas peserta didik sudah sangat baik. Buzan dalam Huda, 2014 strategi pembelajaran mind mapping merupakan metode efektif untuk mengembangkan gagasan-gagasan melalui rangkaian petapeta. Persentase aktivitas belajar peserta didik ini menunjukan bahwa peserta didik memberikan respon positif.

\section{HASIL BELAJAR}

Hasil belajar pada hakikatnya adalah perubahan tingkah laku. Tingkah laku sebagai hasil belajar dalam pengertian yang luas mencakup tiga ranah yaitu: a) ranah kognitif berkenaan dengan hasil belajar intelektul yng terdiri dari enam aspek, yaitu pengetahuan atau ingatan, pemahaman, aplikasi, analisis, sintetis, dan evaluasi, b) ranah afektif berkenaan dengan sikap yang terdiri dari lima aspek, yaitu penerimaan, jawaban atau reaksi, penilaian, organisasi, dan internalisasi, c) ranah psikimotoris berkenaan dengan hasil belajar keterampilan dan kemampuan bertindak yang terdiri dari enam aspek, yaitu gerakan, refleks, keterampilan gerakan dasar, kemampuan perseptual, keharmonisan atau ketepatan, gerakan keterampilan kompleks, dan gerakan ekspresi dan intergreatif (Sudjana, 2011).

\section{Ranah Kognitif}

Hasil belajar ranah kognitif pada penelitian ini diukur melalui hasil tes peserta didik setelah siklus berakhir. Soal tes dibuat berdasarkan jenjang kognitif yang bertingkat. Soal tes dibuat memiliki jenjang kognitif yang berkisar antara CI sampai C4. Soal tes untuk siklus I dan siklus II terdiri dari 20 soal dalam bentuk soal pilihan ganda.

Penentuan persentase ketuntasan belajar peserta didik dapat diketahui dari nilai peserta didik yang mencapai Kriteria Ketuntasan Minimal (KKM) yaitu memperoleh nilai $\geq 75$. Penentuan ketuntasan hasil belajar klasikal diperoleh jika peserta didik mencapai $85 \%$ peserta didik telah mencapai nilainya $\geq 75$.

Nilai ini sesuai berdasarkan pada ketentuan yang telah ditentukan oleh sekolah tempat penelitian. Peserta didik yang tuntas belajar pada siklus I sebanyak 20 orang atau sebesar $76,92 \%$ dan peserta didik yang tidak tuntas sebanyak 6 orang atau sebesar $23,08 \%$. Hal ini disebabkan peserta didik juga belum terbiasa dengan bentuk soal yang tingkat kognitif yang berbeda. Data ditunjukkan pada tabel 4.

Tabel 4. Persentase Ketuntasan Belajar Siswa siklus I

\begin{tabular}{l|l}
\hline KKM $\geq 5$ (Klasikal 85) & $\begin{array}{l}\text { Siklus } \\
(\%)\end{array}$ \\
\hline TUNTAS & $76,92 \%$ \\
TIDAK TUNTAS & $23,08 \%$ \\
\hline
\end{tabular}




\section{JEMS (Jurnal Edukasi Matematika dan Sains)}

Tersedia online di: http://e-journal.ikippgrimadiun.ac.id/index.php/JEMS

Volume 4, Nomor 2, September 2016, hal 121-128

Tindakan pada siklus I menunjukan, sebagian peserta didik masih merasa canggung dan merasa kurang terbiasa dengan pembelajaran metode Mind Mapping yang dikolaborasikan dengan model Student Facilitator and Explaining karena sebelumnya belum pernah dilakukan pembelajaran seperti itu. Tindakan pada siklus II dilakukan dengan beberapa perbaikan, sehingga terjadi peningkatan hasil belajar peserta didik. Pada metode pembelajaran mind mapping, peserta didik dibantu dengan pemberian tugas yang berkaitan dengan penguasaan konsep. Penerapan metode pembelajaran ini merupakan strategi ampuh bagi belajar peserta didik (Huda, 2014). Pada siklus II Nilai ranah kognitif dari 26 peserta didik yang mendapat nilai $\geq 75$ sebanyak 25 peserta didik, 1 orang peserta didik yang tidak tuntas. Ketuntasan belajar peserta didik sebesar 96,15\%. Hal ini menunjukan bahwa adanya peningkatan nilai kognitif pada siklus II. Peserta didik yang tidak tuntas adalah 1 orang atau dengan persentase sebesar 3,85\%. Data ditunjukkan pada tabel 5 .

Tabel 5. Persentase ketuntasan belajar siklus II

\begin{tabular}{ll}
\hline KKM $\mathbf{7 5}$ (Klasikal 85) & $\begin{array}{l}\text { Siklus II } \\
(\%)\end{array}$ \\
\hline TUNTAS & $96,15 \%$ \\
TIDAK TUNTAS & $3,85 \%$ \\
\hline
\end{tabular}

Berdasarkan data yang diperoleh, dapat diketahui bahwa kelas VIII A pada siklus I belum tuntas belajar karena ketuntasan belajar hanya mencapai 76,92\% dan tidak tuntas sebesar $23,07 \%$ sedangkan kriteria ketuntasan belajar yang ditetapkan adalah sebesar $85 \%$.

Hal ini menunjukkan bahwa dari jumlah 26 peserta didik yang mencapai kriteria ketuntasan minimal (KKM) hanya 20 peserta didik yang nilainya $>75$ dan 6 peserta didik belum tuntas. Pada siklus II di ketahui bahwa kelasVIII A telah tuntas belajar karena ketuntasan belajar telah mencapai 96,15\% dan tidak tuntas sebesar $3,85 \%$. Berarti ketuntasan belajar telah mencapai lebih dari kriteria yang ditetapkan yaitu $85 \%$. Peningkatan ketuntasan belajar peserta didik pada ranah kognitif yang ditandai dengan telah mencapai ketuntasan belajar yaitu 96,15\% pada siklus II. Jadi terjadi peningkatan pada ranah kognitif peserta didik dari siklus I ke siklus II sebesar 76,92\% menjadi $96,15 \%$ mengalami peningkatan sebesar 19,23\%. Hasil belajar yang dicapai oleh peserta didik dapat dinilai dengan menggunakan tes dan penilaian.

Berdasarkan data yang diperoleh telah menunjukan adanya peningakatan. Meningkatnya hasil belajar peserta didik pada ranah kognitif karena adanya penerapan metode Mind Mapping dan model Student Facilitator and Explaining yang dikolaborasikan.

\section{Ranah afektif}

Pengukuran yang dilakukan untuk mengukur ranah afektif adalah penilaian sikap peserta didik saat mengikuti pelajaran disetiap pertemuannya yang dilaksanakan pada siklus I dan siklus II. Sikap atau attitude menunujukan adanya kecenderungan yang dimiliki oleh seseorang dalam berperilaku (Pribadi, 2011). Berdasarkan hasil penilaian sikap yang telah dilaksanakan pada akhir siklus I dan siklus II diperoleh data hasil penilaian berturut-turut sebesar 75,77 dan 79,80. Berdasarkan gambar 2. dapat diperoleh perbandingan nilai afektif peserta didik siklus I dan II yaitu sebesar 75,77 terjadi peningkatan menjadi 79,80 sehingga dapat dikatakan bahwa hasil belajar peserta didik dari ranah afektif mengalami peningkatan dari siklus I ke Siklus II sebesar 4,03\% peningkatan nilai rata-rata hasil belajar peserta didik dari ranah afektif pada siklus II dikaitkan dengan model yang digunakan yaitu Student Facilitator and Explaining (SFAE) atau disebut juga peta konsep yang 


\section{JEMS (Jurnal Edukasi Matematika dan Sains)}

Tersedia online di: http://e-journal.ikippgrimadiun.ac.id/index.php/JEMS

Volume 4, Nomor 2, September 2016, hal 121-128

dikolaborasikan dengan mind mapping. Pribadi (2011) berpendapat ranah afektif sangat terkait dengan sikap, emosi, penghargaan, dan penghayatan atau apresiasi terhadap nilai, norma, dan sesuatu yang sedang dipelajari.

\section{Ranah Psikomotorik}

Pengukuran hasil ranah psikomotorik pada penelitian ini diperoleh data pada siklus I sebesar 77,01, pada siklus II mengalami peningkatan sebesar 80. Hasil penilaian selama kegiatan observasi melalui keterampilan peserta didik ketika membuat Mind Mapping dan menjelaskan materi sistem respirasi dengan menggunakan model Student Facilitator and Explaining (SFAE) yang dikolaborasikan menunjukan adanya peningkatan. Keterampilan merupakan eksekusi atau pelaksaan suatu tindakan untuk mencapai hasil tertentu, kemampuan motorik pada umumnya melibatkan aktivitas berupa tindakan dalam keterampilan yang dilakukan baik dengan alat maupun tanpa alat (Pribadi, 2011).

Berdasarkan gambar 3. dapat diperoleh persentase perbandingan nilai hasil belajar peserta didik untuk ranah psikomotorik pada siklus I dan siklus II mengalami peningkatan sebesar 2,99\%. Peningkatan nilai rata-rata hasil belajar peserta didik dari ranah psikomotorik pada siklus II dikaitkan dengan model yang digunakan yaitu Student Facilitator and Explaining (SFAE) atau disebut juga peta konsep yang dikolaborasikan dengan mind mapping. Ranah psikomotorik memiliki kaitan yang erat dengan kemampuan dalam melakukan kegiatan-kegiatan yang bersifat fisik dalam berbagai mata pelajaran. Ranah psikomtorik terdiri atas empat hierarki kemampuan, yaitu imitasi, manipulasi, presisi, dan artikulasi Pribadi (2011).

Azizah (2015), dalam penelitiannya bahwa pelaksanaan pembelajaran dengan metode Mind Mapping dapat meningkatkan hasil belajar. Hal ini dikarena metode Mind Mapping menciptakan suasana pembelajaran yang aktif, kreatif, aktif dan menyenangkan sehingga memudahkan peserta didik dalam menyerap informasi yang diterima, membantu otak untuk mengatur, mengingat, membandingkan, dan memudahkan informasi baru, sehingga peserta didik lebih memahami materi dengan jelas.

Peningkatan aktivitas peserta didik selama kegiatan berlangsung menunjukan bahwa peserta didik telah menerapkan Mind Mapping yang dikolaborasikan dengan peta konsep. Terlihat dari keaktifan peserta didik pada saat membuat mind mapping yang dikolaborasikan dengan model SFAE. Selama kegiatan praktik peserta didik melakukan diskusi kelompok mempresentasikan hasil diskusinya disertai dengan mendemonstrasikan peta konsep di depan kelas dan menyimpulkan sendiri hasil diskusi yang telah dilakukan. Peningkatan hasil ini juga karena tidak adanya perubahan anggota kelompok. Anggota kelompok yang telah terbentuk selama siklus I semakin terjalin, sehingga peserta didik tidak perlu beradaptasi kembali dengan anggota kelompok yang baru.

Metode Mind Mapping merupakan suatu metode mencatat serta menyuluruh dalam satu halaman, Mind Mapping disebut juga dengan peta pemikiran (Porter\&Hernacki, dalam Kurniawati, 2010). Metode mind Mapping mempunyai kelebihan yaitu: memudahkan otak dalam menyerap informasi yang diterima, membantu otak untuk : mengatur, mengingat membandingkan dan memudahkan informasi baru, sehingga lebih dapat memahami materi dengan jelas. Adanya keterlibatan dua belahan otak maka memudahkan peserta didik untuk mengatur dan mengingat segala bentuk informasi, baik secara tertulis maupun secara verbal. 


\section{JEMS (Jurnal Edukasi Matematika dan Sains)}

Tersedia online di: http://e-journal.ikippgrimadiun.ac.id/index.php/JEMS

Volume 4, Nomor 2, September 2016, hal 121-128

Model Student Facilitator and Explaining (SFAE) menuntut penguasaan peserta didik terhadap beberapa keterampilan diantaranya keterampilan berbicara, keterampilan menyimak, keterampilan pemahaman materi, sehingga lebih inovatif, kreatif dan aktif (Huda, 2014).

\section{KESIMPULAN}

Berdasarkan hasil analisis Penelitian dan pembahasan yang telah diuraikan pada bab sebelumnya, maka dapat dibuat kesimpulan sebagai berikut:

Penerapan Metode Mind Mapping dan Model Student Facilitator and Explaining dapat meningkatkan hasil belajar peserta didik kelas VIII A di SMP Aisyiyah Muhammadiyah 3 Malang. Peningkatan hasil belajar peserta didik ranah kognitif berturut-turut yaitu $76,92 \%$ meningkat menjadi $96,15 \%$ untuk ketuntasan belajar peserta didik; dan persentase hasil belajar klasikal sebesar $76,15 \%$ dan $86,73 \%$ dari siklus I ke siklus II, ranah afektif yaitu 75,88 pada siklus I meningkat menjadi 79,80 pada siklus II; sedangkan ranah psikomotorik berturut-turut pada siklus I sebesar 77,01 meningkat menjadi 80 pada siklus II.

\section{SARAN}

Berdasarkan hasil penelitian yang dilakukan, maka saran yang dapat diberikan adalah sebagai berikut:

1. Penerapan metode Mind Mapping dan model Student Facilitator and Explaining yang dikolaborasikan memerlukan pengelolaan kelas yang baik, sehingga seluruh peserta didik memperoleh perhatian yang sama dan akhirnya dapat meningkatkan semua indikator aktivitas.

2. Pembelajaran dengan menggunakan metode Mind Mapping dan model Student Facilitator and Explaining yang dikolaborasikan, membutuhkan pengaturan waktu yang baik karena metode ini membutuhkan banyak waktu.

3. Guru dalam menyusun anggota kelompok harus benar-benar heterogen, peserta didik yang memiliki kemampuan di bawah, sedang, atas dapat berkumpul dalam satu kelompok

4. Guru diberi kebebasan untuk tidak perlu mengubah anggota dalam kelompok karena dapat meningkatkan kekompakan diantara anggota kelompok.

5. Penggunaan metode Mind Mapping dan model Student Facilitator And Explaining dapat digunakan untuk meningkatkan motivasi belajar peserta didik.

\section{DAFTAR RUJUKAN}

Azizah, N.S.2015. Penerapan Metode Mind Mapping Peserta didik Kelas $V \quad S D$ Negeri Jomblangan BangunTapan Bantul. (Online). http://eprints.uny.ac.id/16491/1 ISKRIPSI\%20SULIS.pdf. Diakses 16 April 2016.

Daryanto. 2012. Media Pembelajaran. Bandung: PT. Sarana Tutorial NurainiSejahtera.

Huda, Miftahul. 2014. Model-model Pengajaran dan Pembelajaran : Isu-IsuMetodits dan Paradigmatis. Yogyakarta : Pustaka belajar.

Kurniawati, D. D. 2010. Pengaruh Metode Mind Mapping dan Keaktifan Belajar Peserta didik Terhadap Prestasi Belajar Ilmu Pengetahuan Sosial Pada Peserta didik Kelas VIII Sekolah Menengah Pertama Muhammadiyah 5 Surakarta (Online).

http://eprints.ums.ac.id/8677/2/ 
JEMS (Jurnal Edukasi Matematika dan Sains)

Tersedia online di: http://e-journal.ikippgrimadiun.ac.id/index.php/JEMS

Volume 4, Nomor 2, September 2016, hal 121-128

A210060103.pdf. Di akses 16 April 2016.

Mulyasa. 2013. Implementasi Kurikulum 2013. Bandung: PT. Remaja Rosdakarya.

Pribadi, Benny A. 2011. Model ASSURE untuk Mendesain Pembelajaran Sukses. Jakarta: Dian Rakyat.

Rahmawati. A, Retnowati.R, Kurniasih. S. $\begin{array}{lr}\text { 2012. Penerapan } & \text { Model } \\ \text { Pembelajran } & \text { Student }\end{array}$
Facilitator and Explaining dan Mind Mapping Untuk Meningkatkan Hasil Belajar Biologi Peserta didik Kelas X SMK Farmasi Mutiara Husada Serang Baru. Program Studi Pendidikan Fakultas Keguruan Ilmu Pendidikan Universitas Pakuan Bogor.

Sudjana, Nana. 2011. Penilaian Hasil Proses Belajar Mengajar. Bndung: $\quad$ PT. Remaja Rodaskarya 